\title{
JEKK
}

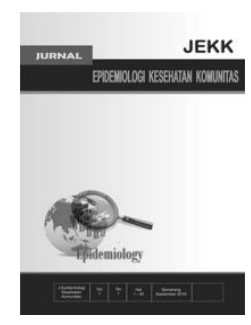

\section{The Relationship between Exclusive Breastfeeding and Diarrhea in Under Six Months Infants in 2017 (Analysis of Indonesian Health Demography Data Survey 2017)}

\author{
Fikriya Rusyda*, Sudarto Ronoatmodjo ** \\ *Program Studi Magister Epidemiologi, Fakultas Kesehatan Masyarakat Universitas Indonesia, Depok 16424 \\ ** Departemen epidemiologi, Fakultas Kesehatan Masyarakat Universitas Indonesia, Lantai 1 Gedung A, \\ Kampus UI Depok, Indonesia
}

\begin{abstract}
Background: Diarrhea is the main cause of malnutrition in underfive children. One of the efforts to prevent diarrhea in infants is exclusive breastfeeding. Exclusive breastfeeding is infant that receives only breast milk without any additional consumption from 0 to 6 months. Under six months infant who are not exclusively breastfed have a higher risk of developing diarrhea than those who are exclusively breastfed.

Methods: This study aims to determine the relationship between exclusive breastfeeding and the incidence of diarrhea in under six months infants in Indonesia. This study analyze secondary data from the 2017 Indonesian Demographic and Health Survey. The sample in this study consist of all live infants aged 0-6 months born to women aged 15-49 years in Indonesia who were successfully interviewed and had a complete answer (no answer missing). After weighting, 1898 samples were obtained.

Result: The result found that the proportion of diarrhea incidence in Indonesia is $9.1 \%$. Meanwhile of all infants, $36 \%$ were not exclusively breastfed. The results showed that there was a significant relationship between infants who were not exclusively breastfed and diarrhea incidence in Indonesia after adjusted by mother's education level, maternal employment status, mother's economic level, area of residence, and latrine ownership ( $\mathrm{PR}=2.12,95 \% \mathrm{CI}=1.46-3.07)$.

Conclusion : Infants who were not exclusively breastfed increase the risk for diarrhea. Therefore it is necessary to have a program to increase the coverage of exclusive breastfeeding. The program can take the form of counseling by health workers in health services.
\end{abstract}

Keywords: Exclusive breastfeeding; diarrhea; infant.

*Penulis korespondensi, fikriyarusyda@gmail.com 


\section{Pendahuluan}

Setiap tahunnya, diare menjadi penyebab kematian pada 525.000 balita. Kasus diare pada balita mencapai 1,7 miliar per tahun dan menjadi penyebab utama terjadinya malnutrisi pada balita. ${ }^{1}$ Di Indonesia diare merupakan salah satu masalah kesehatan yang serius. Hal itu dikarenakan morbiditas dan mortalitasnya yang masih tergolong tinggi. ${ }^{2}$

Diare adalah keluarnya feses cair dengan frekuensi tiga atau lebih per hari. Diare dapat terjadi karena adanya infeksi bakteri, virus, atau parasit. Diare yang parah dapat menyebabkan kehilangan cairan tubuh bahkan kematian terutama pada anak dengan malnutrisi atau memiliki sistem imun yang buruk. Diare dapat dicegah dengan pemberian vaksin maupun dengan menangani faktor-faktor penyebabnya. $^{1,3}$

Diare pada balita umumnya terjadi di negara berkembang di mana sebagian besar memiliki akses air minum, sanitasi, dan higiene yang buruk. Lingkungan yang tidak sehat membuat lebih besar kemungkinan patogen penyebab diare untuk menyebar dengan mudah. Akan tetapi, lingkungan yang sehat juga tidak cukup untuk mencegah terjadinya diare jika bayi rentan terkena penyakit dan tidak efektif untuk diberikan pengobatan. Bayi dengan status gizi yang buruk lebih berisiko untuk terkena penyakit infeksi salah satunya diare. Di sisi lain, diare juga dapat menjadi penyebab semakin buruknya status gizi bayi tersebut. Akhirnya kedua hal itu menjadi siklus yang semakin memperburuk kesehatan bahkan menyebabkan kematian pada bayi. ${ }^{3}$

Pemberian ASI eksklusif dapat menjadi salah satu faktor penting untuk mencegah terjadinya diare. Bayi memiliki sistem imun yang belum matang, sehingga ASI memberikan perlindungan alami terhadap patogen yang masuk ke dalam tubuh bayi baik dalam jangka pendek maupun jangka panjang. ${ }^{4,5}$ ASI mengandung nutrisi, antioksidan, hormon, dan antibodi yang dibutuhkan oleh seorang anak untuk tumbuh dan berkembang secara optimal. ${ }^{3}$ Oligosakarida yang terkandung dalam ASI berperan dalam pencegahan pengikatan patogen dengan permukaan sel di dalam tubuh bayi sehingga efektif melindungi bayi dari penyakit infeksi, salah satunya diare. ${ }^{6}$
Rekomendasi durasi optimal pemberian ASI eksklusif yang ditetapkan oleh WHO adalah 6 bulan. Di sisi lain, ada masyarakat yang beranggapan bahwa bayi setelah 3 atau 4 bulan yang hanya mengkonsumsi ASI tidak mendapatkan nutrisi yang cukup dan hal itu akan mengganggu pertumbuhan bayi. Namun faktanya makanan pendamping ASI yang tersedia di banyak negara berkembang saat ini juga tidak memiliki kandungan gizi yang memadai dan sangat rawan terkontaminasi. Hal itu dapat menjadi penyebab bayi mudah terkena diare. Akhirnya masyarakat menjadi dilema mengenai durasi yang tepat untuk memberikan ASI secara eksklusif. ${ }^{7,8}$

Bayi yang tidak mendapatkan ASI eksklusif lebih berisiko untuk mengalami kematian akibat diare dibandingkan bayi yang mendapatkan ASI eksklusif pada usia 0-50 bulan $(\mathrm{RR}=10,52)$. ASI eksklusif berkontribusi memenuhi kebutuhan nutrisi dan dapat mengurangi paparan kontaminasi cairan atau makanan bagi bayi. Sayangnya, praktik pemberian ASI eksklusif pada beberapa negara masih tergolong rendah. ${ }^{9}$

Studi meta analisis menunjukkan bahwa ASI eksklusif dapat mencegah terjadinya kematian pada bayi terutama terkait penyakit infeksi bahkan sampai 2 tahun pertama kehidupan. ${ }^{10}$ Dalam 6 bulan pertama kehidupan, ASI eksklusif melindungi bayi untuk terkena diare sebesar 6,1 lebih besar dibandingkan penyakit infeksi lainnya. ${ }^{10}$

Cakupan pemberian ASI eksklusif di Indonesia nyatanya belum optimal karena masih terdapat bayi yang sudah diperkenalkan makanan pendamping ASI terlalu dini. Terjadinya penyakit diare pada balita juga belum dapat dikendalikan karena angka kejadinannya yang terus meningkat dari tahun ke tahun. Studi ini bertujuan untuk meneliti hubungan ASI eksklusif dengan kejadian diare pada bayi usia 0-6 bulan di Indonesia menggunakan data SDKI 2017. Dengan penelitian ini diharapkan dapat memberikan masukan untuk upaya peningkatan cakupan ASI eksklusif sebagai salah satu strategi mengurangi angka kejadian diare pada bayi di Indonesia. 


\section{Metode}

Penelitian ini menggunakan data sekunder dari hasil Survei Demografi dan Kesehatan Indonesia (SDKI) tahun 2017. Sampel SDKI 2017 terdiri atas 1.970 blok sensus yang meliputi wilayah perkotaan dan perdesaan. Kerangka sampel yang digunakan adalah Master Sampel Blok Sensus dari hasil Sensus Penduduk 2010 (SP2010) dengan desain sampling yakni sampling dua tahap berstrata. Kuesioner yang digunakan pada penelitian ini adalah kuesioner rumah tangga dan wanita usia subur (WUS) umur 15-49 tahun dengan mengacu pada kuesioner DHS (Demographic Health Surveys) Phase 7 tahun 2015 yang sudah mengakomodasi beberapa isu terbaru sesuai keterbandingan internasional. ${ }^{7}$

SDKI 2017 berhasil mewawancarai 47.963 rumah tangga dengan tingkat respon 99,5\% dan 49.627 wanita dengan tingkat respon $97,8 \% .^{7}$ Populasi sumber penelitian ini adalah seluruh bayi lahir hidup usia 0-6 bulan yang dilahirkan oleh wanita usia 15-49 tahun di Indonesia pada saat survei berlangsung. Seluruh informasi tentang responden didapatkan dari ibunya yang berhasil diwawancarai. Sampel penelitian diambil dengan cara total sampling dari responden dengan data yang lengkap dan tidak ada jawaban yang missing terkait variabel yang dibutuhkan dalam penelitian ini. Setelah data dilakukan cleaning dan pembobotan, didapatkan sampel pada penelitian ini adalah 1898 sampel dari hasil kuesioner wanita usia subur (Form SDKI 17-WUS).

Variabel independen utama pada penelitian ini adalah ASI eksklusif yang dikategorikan menjadi 2, yaitu "ASI eksklusif" dan "tidak ASI eksklusif". Jika wanita usia subur menjawab bahwa responden dalam 24 jam terakhir hanya mengkonsumsi ASI saja tanpa adanya makanan atau minuman tambahan lain maka dikategorikan "ASI eksklusif". Jika wanita usia subur menjawab bahwa responden dalam 2 jam terakhir mengkonsumsi ASI dan makanan atau minuman lainnya atau hanya mengkonumsi makanan atau minuman selain ASI maka termasuk dalam kategori "tidak ASI eksklusif".
Penelitian ini juga menggunakan variabel lain sebagai kovariat yang meliputi tingkat pendidikan ibu, area tempat tinggal, status pekerjaan ibu, status ekonomi ibu, dan kepemilikan jamban. Variabel dependen penelitian ini adalah kejadian diare yang dikategorikan menjadi 2 yaitu "diare" jika wanita usia subur menjawab bahwa responden pernah mengalami diare dan "tidak diare" jika menjawab tidak pernah mengalami diare dalam 2 minggu terakhir.

Penelitian ini menggunakan perangkat Statistical Package for the Social Sciences (SPSS) versi 24 milik laboratorium komputer Fakultas Kesehatan Masyarakat Universitas Indonesia untuk menganalisis data. Analisis data yang dilakukan adalah analisis univariat, bivariat, dan multivariat. Analisis univariat digunakan untuk menggambarkan distribusi dan frekuensi dari setiap variabel yang diteliti, baik variabel independen ataupun dependen. Analisis bivariat digunakan untuk mengetahui hubungan variabel independen dan dependen dengan dilakukan uji chi square dengan confidence interval 95\%. Analisis multivariat merupakan analisis lanjutan dari analisis bivariat dengan dilakukan uji cox regression untuk mengetahui nilai dari asosiasi yaitu prevalence ratio $(\mathrm{PR})$.

\section{Hasil}

Penelitian ini menggunakan sampel sejumlah 1.898 bayi usia $0-6$ bulan di Indonesia. Tabel 1 menunjukkan bahwa sebanyak $9,1 \%$ bayi usia $0-6$ bulan mengalami diare dalam 2 minggu terakhir. Tabel 1 juga menunjukkan sebanyak $36 \%$ bayi usia 0-6 bulan tidak mendapatkan ASI eksklusif. Berdasarkan karakteristik ibu, diketahui sebanyak 25,1\% ibu memiliki tingkat pendidikan rendah, statusnya bekerja sebanyak $29,4 \%$, memiliki tingkat ekonomi yang rendah sebanyak $41,9 \%$, dan bertempat tinggal di desa sebanayk 52,1\%. Berdasarkan kepemilikan jamban, sebanyak $18,7 \%$ bayi usia 0-6 bulan tidak memiliki jamban yang layak. 
Tabel 1. Distribusi Frekuensi ASI Eksklusif, Diare, dan Faktor Lainnya Pada Bayi Usia 0-6 Bulan di Indonesia Berdasarkan Data SDKI 2017.

\begin{tabular}{lcc}
\hline \multicolumn{1}{c}{ Variabel } & Jumlah (n) & Persentase (\%) \\
\hline Diare & 173 & 9,1 \\
$-\quad$ Diare & 1725 & 90,9 \\
$-\quad$ Tidak diare & 683 & 36 \\
\hline ASI Eksklusif & 1215 & 64 \\
$-\quad$ Tidak ASI Eksklusif & & \\
$-\quad$ ASI Eksklusif & 477 & 25,1 \\
\hline Tingkat Pendidikan Ibu & 1421 & 74,9 \\
$-\quad$ Rendah & & \\
$-\quad$ Tinggi & 558 & 29,4 \\
\hline Status Pekerjaan Ibu & 1340 & 70,6 \\
$-\quad$ Bekerja & & \\
$-\quad$ Tidak bekerja & 796 & 41,9 \\
\hline Status Ekonomi Ibu & 1102 & 58,1 \\
$-\quad$ Rendah & & \\
$-\quad$ Tinggi & 989 & 52,1 \\
\hline Area Tempat Tinggal & 909 & 47,9 \\
$-\quad$ Desa & & \\
$-\quad$ Kota & 355 & 81,3 \\
\hline Kepemilikan Jamban & 1543 & \\
$-\quad$ Tidak layak & & \\
$-\quad$ Layak & & \\
\hline
\end{tabular}

Tabel 2. Hasil Analisis Hubungan ASI Eksklusif dan Faktor Lainnya dengan Kejadian Diare Pada Bayi Usia 0-6 bulan di Indonesia Berdasarkan Data SDKI 2017.

\begin{tabular}{|c|c|c|c|c|c|c|c|c|}
\hline \multirow[t]{3}{*}{ Variabel } & \multicolumn{4}{|c|}{ Diare } & \multicolumn{2}{|l|}{ Total } & \multirow{3}{*}{$\begin{array}{c}\text { PR Crude }(95 \% \\
\text { CI) }\end{array}$} & \multirow[t]{3}{*}{ p value } \\
\hline & \multicolumn{2}{|c|}{ Diare } & \multicolumn{2}{|c|}{ Tidak Diare } & \multirow[b]{2}{*}{$\mathrm{N}$} & \multirow[b]{2}{*}{$\%$} & & \\
\hline & $\mathrm{N}$ & $\%$ & $\mathrm{~N}$ & $\%$ & & & & \\
\hline \multicolumn{9}{|l|}{ ASI Eksklusif } \\
\hline Tidak ASI Eksklusif & 92 & 13,5 & 591 & 86,5 & 683 & 100 & $1,08(1,04-1,13)$ & $<0,001^{*}$ \\
\hline ASI Eksklusif & 80 & 6,6 & 1135 & 93,4 & 1215 & 100 & Reference & \\
\hline \multicolumn{9}{|c|}{ Tingkat Pendidikan Ibu } \\
\hline Rendah & 53 & 11,2 & 424 & 88,8 & 477 & 100 & $1,03(0,99-1,08)$ & 0,141 \\
\hline Tinggi & 119 & 8,4 & 1302 & 91,6 & 1421 & 100 & Reference & \\
\hline \multicolumn{9}{|l|}{ Status Pekerjaan Ibu } \\
\hline Bekerja & 45 & 8,1 & 513 & 91,9 & 558 & 100 & $0,98(0,95-1,02)$ & 0,433 \\
\hline Tidak Bekerja & 128 & 9,5 & 1212 & 90,5 & 1340 & 100 & Reference & \\
\hline \multicolumn{9}{|l|}{ Status Ekonomi Ibu } \\
\hline Rendah & 68 & 8,6 & 728 & 91,4 & 796 & 100 & $0,99(0,96-1,03)$ & 0,574 \\
\hline Tinggi & 104 & 9,5 & 998 & 90,5 & 1102 & 100 & Reference & \\
\hline \multicolumn{9}{|c|}{ Area Tempat Tinggal } \\
\hline Desa & 98 & 9,9 & 891 & 90,1 & 989 & 100 & $1,02(0,98-1,05)$ & 0,310 \\
\hline Kota & 75 & 8,3 & 834 & 91,7 & 909 & 100 & Reference & \\
\hline \multicolumn{9}{|l|}{ Kepemilikan Jamban } \\
\hline Tidak layak & 34 & 9,7 & 321 & 90,3 & 355 & 100 & $1,01(0,97-1,05)$ & 0,683 \\
\hline Layak & 138 & 9 & 1405 & 91 & 1543 & 100 & Reference & \\
\hline
\end{tabular}


Tabel 2 menunjukkan hasil analisis bivariat yang dilakukan pada penelitian ini. Berdasarkan uji chi square, diketahui bahwa ada perbedaan yang signifikan antara bayi ASI eksklusif dan bayi yang tidak ASI eksklusif dengan kejadian diare pada balita usia 0-6 bulan $(p$ value $=<0,001)$. Hubungan ASI eksklusif dengan kejadian diare memiliki nilai asosiasi PR sebesar 1,08 (95\% CI 1,04-1,13). Artinya bayi yang tidak mendapatkan ASI eksklusif memiliki risiko 1,08 kali lebih tinggi untuk mengalami diare dibandingkan bayi yang mendapatkan ASI eksklusif. Variabel lainnya yaitu tingkat pendidikan ibu, status pekerjaan ibu, status ekonomi ibu, area tempat tinggal, dan kepemilikan jamban tidak menunjukkan hubungan yang signifikan terhadap kejadian diare pada bayi usia 0-6 bulan di Indonesia.

Hasil analisis multivariat disajikan dalam Tabel 3. Model yang digunakan dalam analisis multivariat adalah untuk menentukan faktor kausal dari adanya diare pada balita. Analisis ini didasarkan pada hasil bivariat. Jika suatu hubungan variabel memiliki nilai $\mathrm{p}<0,25$ pada analisis bivariat maka variabel independen dapat dimasukkan ke dalam model multivariat. Variabel independen dengan hasil analisis bivariat yang menunjukkan nilai $\mathrm{p}>0,25$ tetap berkesempatan untuk dimasukkan ke dalam model multivariat. Hal itu jika secara teori ada hubungan yang dapat menjelaskan antara variabel independen tersebut dengan kejadian diare. Oleh sebab itu semua variabel dari analisis bivariat dimasukkan ke dalam model multivariat.

Model akhir analisis multivariat hubungan antara ASI eksklusif dengan kejadian diare pada bayi usia 0-6 bulan di Indonesia menjelaskan bahwa ASI eksklusif memiliki hubungan yang signifikan ( $\mathrm{p}$ value $=<0,001$ ) dengan kejadian diare setelah dikontrol faktor tingkat pendidikan ibu, status pekerjaan ibu, status ekonomi ibu, area tempat tinggal, dan kepemilikan jamban. Nilai PR menunjukkan angka $2,12(95 \% \mathrm{CI}=1,46-3,07)$ artinya responden yang tidak mendapatkan ASI eksklusif berisiko 2,12 kali lebih tinggi untuk mengalami kejadian diare dibandingkan responden yang mendapatkan ASI eksklusif.

\section{Pembahasan}

Berdasarkan hasil analisis data, diketahui bahwa banyaknya kejadian diare pada bayi usia 0-6 bulan di Indonesia mencapai 9,1\%. Salah satu faktor penting yang berhubungan dengan kejadian diare pada bayi adalah ASI eksklusif. Hasil penelitian ini menunjukkan bahwa cakupan ASI eksklusif pada bayi usia 0-6 bulan adalah sebanyak 64\%. Berdasarkan data WHO, secara global saat ini bayi usia 0-6 bulan yang mendapatkan ASI eksklusif baru mencapai $44 \% .^{11}$

Jika didasarkan pada status kejadian diare, ada sebanyak $13,5 \%$ yang mengalami diare pada bayi yang tidak ASI eksklusif. Sedangkan kejadian diare pada bayi dengan ASI eksklusif adalah sebanyak $6,6 \%$. Hal itu menunjukkan bahwa kejadian diare lebih tinggi terjadi pada bayi yang tidak ASI eksklusif dibandingkan bayi yang ASI eksklusif. Hasil ini sejalan dengan penelitian Tamimi dkk, yang menunjukkan bahwa proporsi diare lebih tinggi pada bayi yang tidak ASI eksklusif $(29,5 \%)$ dibandingkan bayi yang ASI eksklusif $(7,9 \%)^{12}$

WHO merekomendasikan pemberian ASI eksklusif selama 6 bulan pertama kehidupan yang dilanjutkan dengan pemberian ASI dan makanan pendamping yang tepat samapi 2 tahun atau lebih. Pada tahun 2025 secara global ada 6 target nutrisi yang harus dicapai, salah satunya adalah meningkatkan angka pemberian ASI eksklusif di 6 bulan pertama yaitu mencapai $50 \%{ }^{13}$ Hasil pada penelitian ini menunjukkan bahwa Indonesia sudah mampu mencapai target yang ditetapkan yaitu ada sebanyak $64 \%$ bayi usia $0-6$ bulan yang mendapatkan ASI eksklusif. Akan tetapi capaian tersebut masih harus ditingkatkan dalam rangka meminimalisir angka kejadian diare.

Berdasarkan hasil analisis multivariat, ditunjukkan bahwa ASI eksklusif memiliki hubungan yang bermakna dengan kejadian diare pada bayi usia 0-6 bulan setelah dikontrol oleh faktor tingkat pendidikan ibu, status pekerjaan ibu, status ekonomi ibu, area tempat tinggal, dan kepemilikan jamban ( $\mathrm{PR}=2,12$, 95\% CI $=1,46-3,07)$. Hasli penelitian ini sejalan dengan penelitian Duijts et al. yang 
menunjukkan bahwa bayi yang mendapatkan ASI eksklusif selama 6 bulan pertama memiliki risiko yang lebih rendah untuk terserang penyakit saluran cerna dibandingkan bayi yang tidak pernah mendapatkan ASI (AOR $=0,46$, 95\% CI $=0,14-1,59) .{ }^{14}$ Penelitian Rini dan Rohayati juga menunjukkan bahwa bayi yang tidak mendapatkan ASI eksklusif lebih berisiko menderita diare dibandingkan yang mendapatkan ASI eksklusif (OR $=4,67,95 \%$ $\mathrm{CI}=(1,25-17,44) .{ }^{15}$ Menurut Ehlayel et al. memberikan ASI secara eksklusif dengan waktu yang singkat, yaitu kurang dari 4-6 bulan dapat memberikan risiko 2,18 kali bagi anak untuk terkena diare. ${ }^{16}$

Ibu yang dapat menyusui selama 6 bulan secara eksklusif merupakan faktor penting untuk melindungi bayi dari infeksi. Dari perspektif nutrisi, usia bayi merupakan masa yang kritis dan rentan. Jaringan dan organ yang terlibat dalam metabolisme nutrisi dinilai belum matang sehingga bayi akan memberikan perlindungan yang rendah terhadap asupan nutrisi yang tidak sesuai. Makanan selain ASI dapat menurunkan perkembangan bakteri baik seperti Lactobacillus dan Bifidobacteri yang berfungsi menciptakan suasana $\mathrm{pH}$ yang lebih tinggi di usus dan meningkatkan pertumbuhan patogen sehingga usus bayi lebih rentan terkena infeksi. Apalagi jika hal ini dikaitkan dengan kondisi negara berkembang yang memiliki standar hygiene dan akses air bersih yang belum optimal. Bayi yang dikenalkan makanan selain ASI terlalu dini kemungkinan akan terkena infeksi dari kontaminasi botol, susu, atau makanan yag diberikan. Artinya, di negara berkembang bayi lebih berisiko jika dibandingkan di negara maju untuk terkena infeksi salah satunya diare. Oleh karena itu, ketika bayi dikenalkan makanan selain ASI pada usia kurang dari 6 bulan dapat memberikan konsekuensi yang serius bagi kesehatan bayi. ${ }^{16,17,18}$

Dengan menggunakan desain studi cross sectional, asosiasi yang dihasilkan pada penelitian ini dapat dikatakan kurang akurat untuk menggambarkan hubungan kausalitas antara variabel independen dengan dependen. Selain itu pada penelitian ini juga dapat terjadi bias informasi. Berdasarkan kuesioner SDKI 2017, penentuan ASI eksklusif pada penelitian ini hanya didasarkan pada keterangan ibu yang ditanyakan mengenai riwayat pemberian makanan pada bayi selama 24 jam terakhir sebelum diwawancara. Artinya jawaban ibu kurang bisa menggambarkan kondisi sesungguhnya dari bayi karena hanya ditanyakan untuk waktu tertentu saja. Selain itu berkaitan dengan diare, penentuannya juga hanya didasarkan pada ingatan ibu tentang riwayat kejadian diare pada bayi selama 2 minggu terakhir sebelum diwawancara. Riwayat diare juga hanya didasarkan pada persepsi ibu, bukan atas pemeriksaan tenaga kesehatan yang mengerti tentang kondisi bayi yang dikategorikan mengalami diare. Sama halnya dengan ASI eksklusif, jawaban tersebut sebenarnya kurang dapat mewakili kejadian diare yang dialami oleh bayi. Oleh karena itu pengukuran variabel baik independen maupun dependen pada penelitian ini dapat dikatakan kurang akurat. Namun dapat dikatakan bahwa bias informasi yang terjadi bersifat non diferensial karena kemungkinan terjadinya kesalahan dapat terjadi pada 2 kelompok.

Berkaitan dengan pengukuran variabel ASI eksklusif juga tidak digambarkan secara detail mengenai bagaimana cara ibu memberikan ASI kepada bayinya. Ada kemungkinan bahwa ibu dapat memberikan ASI secara tidak langsung seperti melalui botol dot atau alat makan lainnya yang itu bisa menjadi potensi risiko untuk anak terkontaminasi bakteri. Kontaminasi dapat terjadi karena penggunaan sumber air yang tidak steril saat membersihkan botol. ${ }^{18} \mathrm{Hal}$ ini dapat menjadi salah satu faktor risiko untuk terjadinya diare pada bayi yang tidak diperhitungkan pada penelitian ini.

\section{Kesimpulan}

Penelitian ini menunjukkan bahwa terdapat hubungan yang bermakna antara bayi usia 0-6 bulan yang tidak diberikan ASI eksklusif dengan kejadian diare di Indonesia. Bayi yang tidak mendapatkan ASI eksklusif berisiko sebesar 2,12 kali menderita diare dibandingkan bayi dengan ASI eksklusif. Hasil penelitian ini masih dapat dipengaruhi oleh adanya bias informasi dan kemungkinan faktor lain yang tidak diperhitungkan. Oleh karena 
itu, diharapkan adanya penelitian lanjutan dengan pengukuran variabel yang lebih akurat serta mengikutsertakan faktor risiko lainnya.

Dalam rangka pengendalian kejadian diare pada bayi di Indonesia, diperlukan adanya program dalam rangka peningkatan cakupan ASI eksklusif. Program peningkatan cakupan ASI eksklusif dapat melalui penyuluhan oleh tenaga kesehatan di pelayanan kesehatan. Selanjutnya ibu dari bayi dapat diberikan buku monitoring untuk melihat perilaku pemberian ASI eksklusif dan untuk dievaluasi ke depannya.

\section{Ucapan Terima kasih}

Ucapan terima kasih disampaikan kepada pihak penyedia data SDKI 2017 yaitu Badan Pusat Statistik (BPS), Badan Kependudukan dan Keluarga Berencana Nasional (BKKBN), dan Kementrian Kesehatan (Kemenkes). Tak lupa kepada dosen di Departemen Epidemiologi Fakultas Kesehatan Masyarakat Universitas Indonesia yang telah memfasilitasi, memotivasi, membimbing, dan mengarahkan hingga terselesaikannya penelitian ini.

\section{Daftar Pustaka}

1. World Health Organization. Diarrhoeal disease. 2017 [Cited 2021 May 8]. Available from: https://www.who.int/news -room/fact-sheets/detail/diarrhoeal-disease.

2. Kementerian Kesehatan RI. 2011. Situasi diare di Indonesia. J Bul Jendela Data Inf Kesehat. Jakarta: Kementrian Kesehatan RI.

3. WHO; UNICEF. 2009. Diarrhoea: Why children are still dying and what can be done. [Cited 2021 May 5]. Available from: https://www.who.int/publications/i/ item/9789241598415.

4. Story L, Parish T. 2008. Breastfeeding helps prevent two major infant illnesses. Internet J Alied Heal Sci Pract. 6(3):1-5.

5. Ugboko HU, Nwinyi OC, Oranusi SU, Oyewale JO. 2020. Childhood diarrhoeal diseases in developing countries. Heliyon. 6(4):e03690.

6. Morrow AL, Ruiz-Palacios GM, Jiang X, Newburg DS. 2005. Human-milk glycans that inhibit pathogen binding protect breast-feeding infants against infectious diarrhea. Am Soc Nutr Sci. 135(5):1304-7.

7. BKKBN. 2017. Survey demografi dan kesehatan Indonesia. Jakarta: Kementrian Kesehatan RI.

8. Kramer MS, Kakuma R. 2002. The optimal duration of exclusive breastfeeding: A systematic review. Switzerland: World Health Organization. [Cited 2021 May 5]. Available from: https://www.who.int/nutrition/publications /optimal_duration_of_exc_bfeeding_ review_eng.pdf.

9. Lamberti LM, Fischer CLW, Noiman A, Victora C, Black RE. 2011. Breastfeeding and the risk for diarrhea morbidity and mortality. BMC Public Health. 11(3):1-12.

10. Victora CG, Barros AJD. 2000. Effect of breastfeeding on infant and child mortality due to infectious diseases in less developed countries: A pooled analysis. Lancet. 355(9202):451-5.

11. World Health Organization. 2021. Infant and young child feeding. [Cited 2021 May 12]. Available from: https://www.who.int/news-room/factsheets/detail/infant-and-young-childfeeding.

12. Tamimi MA, Jurnalis YD, Sulastri D. 2016. Hubungan pemberian ASI eksklusif dengan kejadian diare pada bayi di wilayah Puskesmas Nanggalo Padang. J Kesehat Andalas. 5(1):149-53.

13. World Health Organization. 2017. Protecting, promoting and supporting breastfeeding in facilities providing maternity and newborn services.. Geneva: World Health Organization. 
14. Duijts L, Jaddoe VWV, Hofman A, Moll HA. 2010. Prolonged and exclusive breastfeeding reduces the risk of infectious diseases in infancy. Pediatrics. 126(1).

15. Rini S, Rohayati R. 2017. Kejadian diare pada bayi dengan pemberian ASI. J Ilm Keperawatan Sai Betik. XI (2):153-7.

16. Ehlayel MS, Bener A, Abdulrahman HM. 2009. Protective effect of breastfeeding on diarrhea among children in a rapidly growing newly developed society. Turk $\mathbf{J}$ Pediatr. 51(6):527-33.

17. El S, Kearney J. 2014. Six months of exclusive breastfeeding recommendation: How applicable is the universal exclusive breastfeeding recommendation policy? African J Food, Agric Nutr Dev. 14(4):9071-84.

18. Hanieh S, Ha TT, Simpson JA, et al. 2015. Exclusive breast feeding in early infancy reduces the risk of inpatient admission for diarrhea and suspected pneumonia in rural Vietnam: A prospective cohort study Global health. BMC Public Health. 15(1):1-0. 